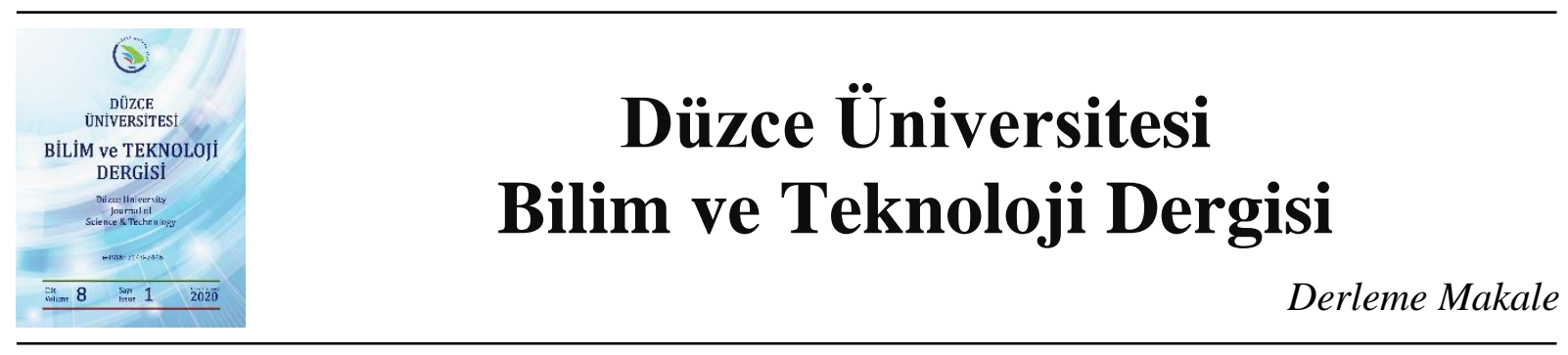

\title{
Katı Atık Yönetiminden Meydana Gelebilecek Sera Gazları ile Matematiksel Tahminleri Üzerine Literatür Araştırması
}

\author{
Kazim Onur DEMIRARSLAN ${ }^{\text {a** }}$ \\ ${ }^{a}$ Çevre Mühendisliği Bölümü, Mühendislik Fakültesi, Artvin Çoruh Üniversitesi, Artvin, TÜRKIYE \\ * Sorumlu yazarın e-posta adresi: onurdemirarslan@artvin.edu.tr \\ DOI: $10.29130 /$ dubited.568588
}

\begin{abstract}
ÖZET
Katı atıklar ve sera gazı emisyonları birbirlerinden farklı çevre problemi gibi algılanmalarına rağmen birbirlerine oldukça bağımlı bir yapıya sahiptirler. Kentlerde oluşan katı atıkların toplanmasından bertaraf edilmelerine kadar geçen süreçte, atmosfere önemli miktarda sera gazı emisyonu salınmaktadır. Bu oran özellikle bertaraf edilme sürecinde daha da artmaktadır. Vahşi-düzenli depolama, kompostlaştırma, yakma gibi konvansiyonel yöntemler de başlıca sera gazı kaynaklarıdır. Tüm bu işlemler sırasında oluşabilecek emisyon miktarlarının bilinmesi, gerekli önlemlerin alınabilmesi açısından oldukça önemlidir. Dünya genelinde yapılan çalışmalar sonucunda; sera gazı emisyon miktarlarının öngörülebilmesi için birçok matematiksel model geliștirilmiş ve kullanılmıştır. Bu modeller yardımıla emisyon miktarları tahminleri yapılarak, azaltılma yoluna gidilmesi ya da tamamen yok edilebilmesi amacıyla gerekli çalışmalar yapılabilmektedir. Yapılan bu çalışmada atık yönetiminden kaynaklanan sera gazı emisyonları incelenmiş ve modelleme yöntemleri hakkında bilgiler verilmiş; ileride yapılabilecek olan atık yönetiminden kaynaklı emisyonların modellenmesi konusundaki çalışmalara kaynak olması amaçlanmıştır.
\end{abstract}

Anahtar Kelimeler: Atık Yönetimi, Emisyon azaltma, Matematiksel modelleme, Sera gazı

\section{Literature Survey on Greenhouse Gases and Mathematical Estimates From Solid Waste Management}

\begin{abstract}
Although solid wastes and greenhouse gas emissions are different environmental problems, they are highly dependent. A significant amount of greenhouse gas emissions are released to the atmosphere in the process from the collection of solid wastes in the cities to the disposal. This rate increases especially in disposal operations. Conventional methods such as wild-landfill, composting and incineration are the main sources of greenhouse gas. Knowing the amount of emissions that may occur from all these operations is very important in order to take necessary measures. As a result of the studies carried out in the world, many mathematical models have been developed and used for predicting greenhouse gas emissions. With the help of models, necessary measures can be taken in order to reduce the amount of emissions or to prevent them completely. In this study, greenhouse gas emissions from waste management were examined and information about modeling methods was given. With this study, it is aimed to be the source of studies on modeling of emissions from future waste management.
\end{abstract}

Keywords: Waste Management, Emission reduction, Mathematical modeling, Greenhouse gas

Geliş: 21/05/2019, Düzeltme: 28/05/2019, Kabul: 28/08/2019 


\section{GIRIS}

Çevre sorunları çağın en büyük problemlerinden biri haline gelmiştir. Nüfus artışı ve buna bağlı olarak kentleşme ile teknolojideki ve endüstrideki ilerlemeler birtakım olumsuzlukları da beraberinde getirmektedir. Hava, su, toprak kirliliği, katı atıklar sözü edilen problemlerin başında bulunmaktadır. Çevre problemlerinin bu denli çeşitli ve bir o kadar da yıkıcı olmasının, dünya nüfusunun hızlı artışı ile doğrudan bağlantılı olabileceği düşünülmektedir. Sözü edilen sorunlardan biri, özellikle hava kirliliğinin doğrudan bir sonucu olan iklim değişikliğidir. Fosil yakıt tüketimi ve arazi kullanımındaki oransal değişiklikler atmosfere yüksek miktarda sera gazlarının salınımında etken rol oynamaktadır. Bu gazlar arasında karbon dioksit, metan ve azot dioksit bulunmakta ve bu gazların seviyesindeki artışlar, güneş ışınlarının daha yüksek miktarlarda absorbe edilmesine yol açmaktadır [1]. İklim değişikliğine kavram olarak bakıldığında; yağış, sıcaklık, rüzgâr, basınç gibi iklim elementlerinin belli bir zaman aralığındaki ortalama davranışlarının istatistiksel veya sistematik olarak değişimleri için kullanıldığı görülmektedir. İnsan etkileri doğrudan veya dolaylı olarak küresel iklim elementlerine etki etmekte ve bu da iklim değişikliği olarak yorumlanmaktadır [2]. Endüstri devriminin yaşandığı 1700'lü yıllardan beri insanoğlu enerji üretimi, ısınma ve soğutma gibi nedenlerle fosil yakıtları kullanmış ve atmosfere önemli miktarda sera gazı yaymıştır [3]. IPCC (Intergovernmental Panel on Climate Change, Hükümetlerarası iklim değişikliği paneli)'nin 5. değerlendirme raporuna göre atmosferdeki $\mathrm{CO}_{2}$, metan ve $\mathrm{N}_{2} \mathrm{O}$ konsantrasyonlarının son 800.000 yıl içerisinde daha önce görülmemiş bir şekilde arttığı ve bu duruma da 1750 y1lından beri insanoğlunun aktivitelerinin neden olduğu belirtilmiştir. Küresel yıllık ortalama sıcaklığın her yüzyılda bir $0,69^{\circ} \mathrm{C}$ oranında arttı̆̆ 1 da raporda ayrıca bahsedilmektedir. [4]. Yine IPCC raporuna göre insan aktiviteleri nedeniyle sanayi öncesi döneme göre küresel sıcaklıkların yaklașık olarak $1{ }^{\circ} \mathrm{C}$ arttığ 1 ve bu oranın $2030-2052$ yılları arasında ise $1,5^{\circ} \mathrm{C}$ olacağ 1 belirtilmektedir [5]. Sera gazı olarak bilinen ve atmosferdeki ısıyı tutan gazlar arasında $\mathrm{CO}_{2}$ önemli bir rol oynamaktadır. Kömür, doğalgaz, petrol gibi fosil yakıtların yakılmasıyla, katı atıklardan, ağaç ürünlerinden ve ayrıca kimyasal reaksiyonlardan meydana gelerek atmosfere karışmaktadır [6]. $\mathrm{CO}_{2}$ 'in dünyadaki enerji balansı üzerinde önemli bir rol oynadığ 1 ve ana sera gazlarından biri olduğu bilim adamları tarafından 1800'lü yılların ortalarından bu yana bilinmektedir [7]. Metan iklim değişikliğine neden olan ikinci en büyük sera gazlarındandır. Kaynaklarına bakıldığında fosil yakıtların çıkarılması, işlenmesi, kentsel katı atıkların toplanması, bertaraf edilmesi, çiftlikler, tarım, atıksu tesisleri gibi yerler olduğu görülmektedir [8].

Azot oksit $\left(\mathrm{N}_{2} \mathrm{O}\right)$ küresel iklim değişikliğine neden olan sera gazlarından olup aynı zamanda ozon tabakasına da zarar vermektedir [9]. $\mathrm{CO}_{2}$ 'den 300 kat daha güçlü bir sera gazı olan [10] ve yarılanma ömrü 110 y1lı bulan $\mathrm{N}_{2} \mathrm{O}$ [11] özellikle çiftliklerden, tarımsal aktivitelerden [12] ve atık yönetim sistemlerinden meydana gelmektedir [13].

Kyoto Protokolü'nde belirtilen insan aktiviteleri sonucunda meydana gelen sera gazları ve etkileri ise Tablo 1' deki gibi belirtilmiştir. Tabloda belirtilen "Küresel Isınma Potansiyeli" kavramı belirli bir zaman sınırında (normalde 100 yıl) 1 birim $\mathrm{CO}_{2}$ 'nin meydana getirdiği isınmaya olan oranı olarak açıklanmaktadır [14].

Tablo 1. Kyoto Protokolünde belirtilen insan aktiviteleri sonucunda meydana gelen sera gazları

\begin{tabular}{clc}
\hline \multicolumn{1}{c}{ Seragazı } & & Küresel Isınma Potansiyeli \\
\hline Karbondiosit & $\left(\mathrm{CO}_{2}\right)$ & 1 \\
Metan & $\left(\mathrm{CH}_{4}\right)$ & 25 \\
Diazotmonoksit & $\left(\mathrm{N}_{2} \mathrm{O}\right)$ & 298 \\
Hidroflorokarbonlar & $(\mathrm{HFC})$ & $124-14800$ \\
Perflorokarbonlar & $(\mathrm{PFC})$ & $7390-12200$ \\
Kükürtkegzaflorid & $\left(\mathrm{SF}_{6}\right)$ & 22800 \\
Azottriflorid & $\left(\mathrm{NF}_{3}\right)^{3}$ & 17200 \\
\hline
\end{tabular}

Dünyadaki sera gazı emisyonu kaynakları Şekil 1'de görülebilmektedir. Şekil 1'de verildiği üzere katı atıklarsa toplam sera gazı emisyon kaynaklarının \%2'sini oluşturmaktadır. Katı atık yönetiminde 
atıkların toplanmasından bertaraf edilmesine kadar olan süreçte sera gazı emisyonları atmosfere karışabilmektedir.

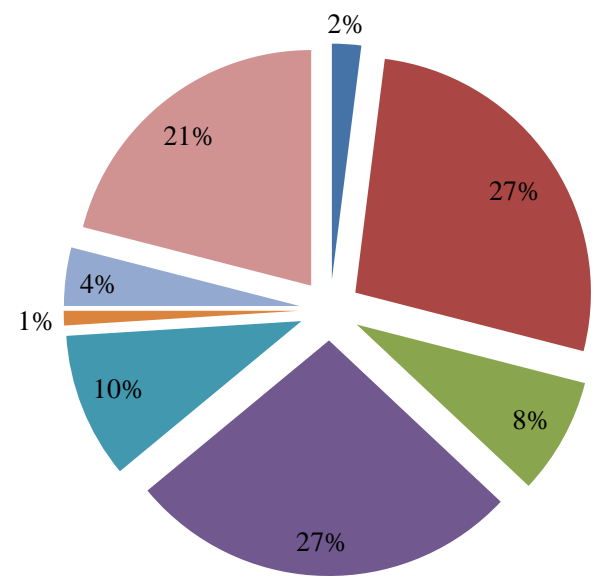

$$
\begin{array}{lll}
\square \text { Atıklar } & \text { Enerji } & \square \text { Üretim sanayi } \\
\square \text { Taşımacılık } & \square \text { Diğer sektörler } & \square \text { Kaçak emisyonlar } \\
\square \text { Endüstriyel prosesler } & \square \text { Tarım } &
\end{array}
$$

Şekil 1. $\mathrm{CO}_{2}$ eşdeğeri toplam sera gazı emisyonlarının kaynakları [15]

Katı atıkların bertaraf edilmesinde kullanılan yöntemlerden biri olan vahşi depolama faaliyeti, düzenli depolama ve yakma işlemlerine kıyasla daha önemli miktarlarda sera gazının atmosfere karışmasına neden olmaktadır. İster vahşi depolama olsun ister denetimli ve düzenli olsun tüm bu işlemler neticesinde meydana gelen sera gazları içerisinde en önemlileri $\mathrm{CO}_{2}$, metan ve $\mathrm{N}_{2} \mathrm{O}$ olmaktadır. Yapılan bu çalışmada katı atık yönetimi sonucunda meydana gelen sera gazları, literatür taraması yapılarak incelenmiştir. Ayrıca dünyada kullanılan ve mevcut emisyonların matematiksel olarak modellemesini sağlayan yöntemler de bu çalışmada ele alınmıştır.

\section{KATI ATIK KAVRAMI ve KATI ATIKLARIN YÖNETIMI}

Katı Atıklar; evsel, ticari ve/veya endüstriyel faaliyetler sonucu oluşan, son tüketici tarafından artık işe yaramayacağı gerekçesiyle atılan, atıl kalması halinde toplum sağlığını kötü etkileyebilecek; ancak, ekonomik olarak tekrar kullanımları mümkün olabilecek düzenli biçimde uzaklaştırılması gereken maddeler olarak tanımlanabilmektedir $[16,17]$. Katı atıklar kaynaklarına göre incelendiğinde evsel (kentsel) kat1 atıklar, endüstriyel nitelikli katı atıklar, tıbbi atıklar, özel nitelikli atıklar olarak sınıflandırılabilir [18]. Kentsel katı atık kavramı ise özellikleri bölgeden bölgeye değişen ve kentsel alanlarda meydana gelen, heterojen olarak toplanan atıkları ifade etmektedir [19]. Kentsel katı atıklar bozunabilen ve bozunamayan atıklar, paketler, kartonlar, bahçe ve mutfak atıkları gibi organik atıklar, evlerden, ticarethanelerden ve endüstri tesislerinden meydana gelen inorganik atıklardan oluşmaktadır [20]. Kentlerde katı atık oluşumu; topografya, mevsim, mutfak alışkanlıkları, toplama sıklığı, ekonomik koşullar, geri dönüşüm kültürü, yeniden kullanma ve bölgesel kültürleri içeren karmaşık bir süreçtir [21]. Atık yönetimi çevre ve insan sağlığının korunması açısından kentsel altyapının önemli bir parçasını oluşturmakta ve teknik bir konu olmasının yanı sıra, politik bir yönü de bulunmaktadır [22]. Katı atık yönetiminde yaşanan aksaklıklar örneğin; toplanması ve bertaraf edilmesinde yapılan yanlışlıklar, toprak, su ve hava kirliliğine neden olabilmektedir [23]. Kentsel atıkların uygun olmayan yönetimi sonucunda hava toprak ve su kirliliği oluşmakta, atıkların kontrolsüz şekilde bertaraf edilmelerinin ve özellikle yakılmalarının hava kirliliğine önemli ölçüde katkısı bulunmaktadır. Ayrıca organik atıklarda ayrışma ve çürüme süreci sonucunda oluşan sera gazları da atmosfere karışmaktadır [24]. 


\section{KATI ATIKLAR ve SERA GAZLARI}

Katı atıkların bertaraf edilmesinde kullanılan yöntemlerin bazıları atmosfere sera gazı yayılmasına neden olmaktadır. Sera gazlarının \%3,5'i atıklardan meydana gelmekte ve tahminen küresel antropojenik kaynakların 1/5'ine denk gelmektedir. Bir diğer araştırmaya göre ise bu oran \%3-5 arasında değişmektedir. Özellikle depolama alanlarında oluşan metan gazlarının toplam sera gazı emisyonlarının \%15' ine eşit olduğu belirtilmektedir. Diğer kaynaklara nazaran oranların düşük olmasına karşın her geçen gün artan dünya nüfusuna bağlı olarak atık üretimi de artmakta ve dolayısıyla oluşan sera gazları da artmaktadır. Bu nedenle sera gazları azaltılması gereken kaynaklar arasındadır [25, 26, 27]. Ancak aynı anda birçok kaynaktan sera gazı yayılımı olduğundan ve ayrıca bu kaynakları birbirlerinden ayırt etmenin imkânsızlığından dolayı; atık kaynaklı sera gazlarının küresel ısınmaya katkısını açıklamak oldukça zor olmaktadır ve bu nedenle sera gazı emisyonları bir bütün olarak ele alınmalı ve öylece azaltılması yoluna gidilmelidir [26, 28].

Küresel ısınmaya büyük ölçüde katkıda bulunan sera gazlarının en önemlileri $\mathrm{CO}_{2}, \mathrm{CH}_{4}$ ve $\mathrm{N}_{2} \mathrm{O}$ 'dur ve bu üç kirletici atık yönetiminin her aşamasında meydana gelmektedir [29]. Şekil 2'de sera gazı meydana gelen atık yönetiminin aşamaları gösterilmiştir.

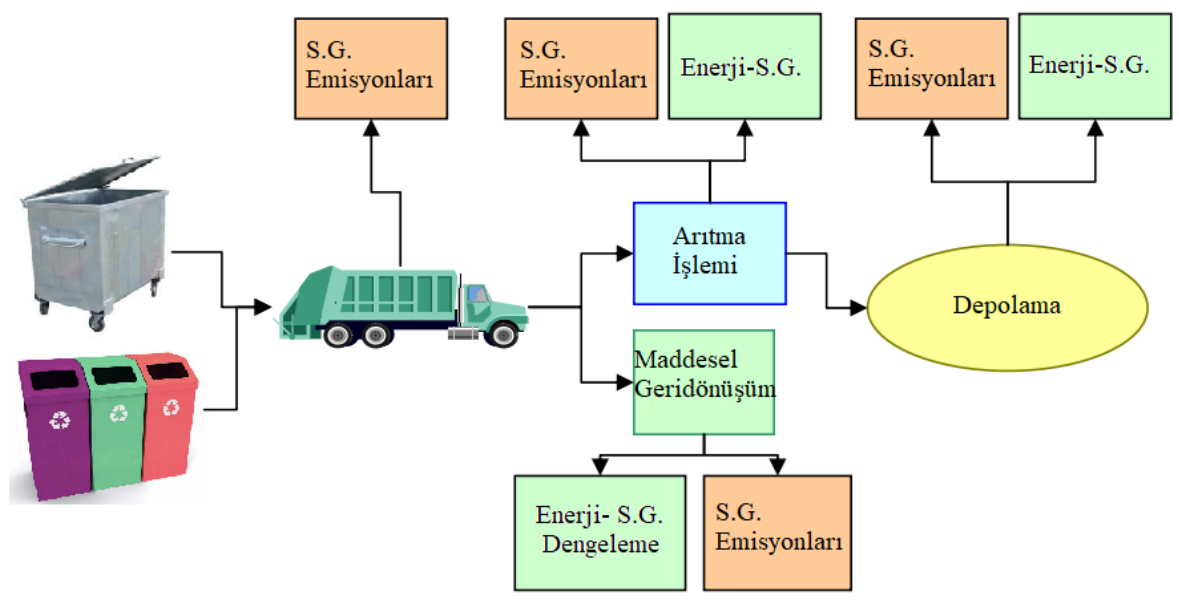

Şekil 2. Atık yönetim sistemi ve oluşan sera gazları (S.G.) emisyonları [26]

2014 yılına ait İngiltere kaynaklı bir araştırmaya göre sera gazı emisyonlarının \%23'ü taşımacılık, \%31 ' $\mathrm{i}$ enerji üretimi, \%9'u tarım sektörü, \%12'si evsel kaynak, \%17'si üretim kaynaklı olup; kalan \%4'ü ise diğer kaynaklardan meydana gelmektedir. Bu oranların içerisinde atık yönetimi ise \%4'lük bir yer kaplamaktadır. $\mathrm{Bu}$ atıkların oluşturduğu toplam emisyonlar içinde \%93 lük bir oranı da metan oluşturmaktadır [30]. Kanada'nın Ontario eyaletinde sera gazı emisyonlarının \%5,3'ünün atıklardan oluştuğu, 2013 yılında ise atık depolamadan 12,3 milyon ton $\mathrm{CO}_{2}$ eşdeğeri metan gazı emisyonu meydana geldiği belirtilmiştir [31]. Güney Kore'de atıklardan oluşan metan emisyonunun 465000 ton olduğu hususu resmi kayıtlara geçmiştir [32]. Depolama alanları ABD'de çiftlik hayvanlarından sonra ikinci en önemli antropojenik $\mathrm{CH}_{4}$ kaynaklarındandır ve küresel olarak düşünüldügüünde toplam $\mathrm{CH}_{4}$ miktarının \%2'sini meydana getirmektedir [33]. Endonezya'da inşa edilmiş bir depolama tesisinde yılda 25 bin ton metan oluştuğu; bunun da 500 bin ton $\mathrm{CO}_{2}$ eşdeğeri sera gazına eşit olduğu belirtilmektedir [34]. Pakistan'da ise atık yönetiminin düşük miktarlarda emisyona neden olduğu ve ülkenin sera gazı emisyonunun sadece \%2'sini oluşturduğu yapılan çalışmalarda gösterilmiştir [35]. Avrupa Birliği üye ülkelerinde 1990-2016 yılları arasında atık yönetiminden oluşan sera gazı miktarlarını gösteren grafik ise Şekil 3'te verilmiştir [36]. 


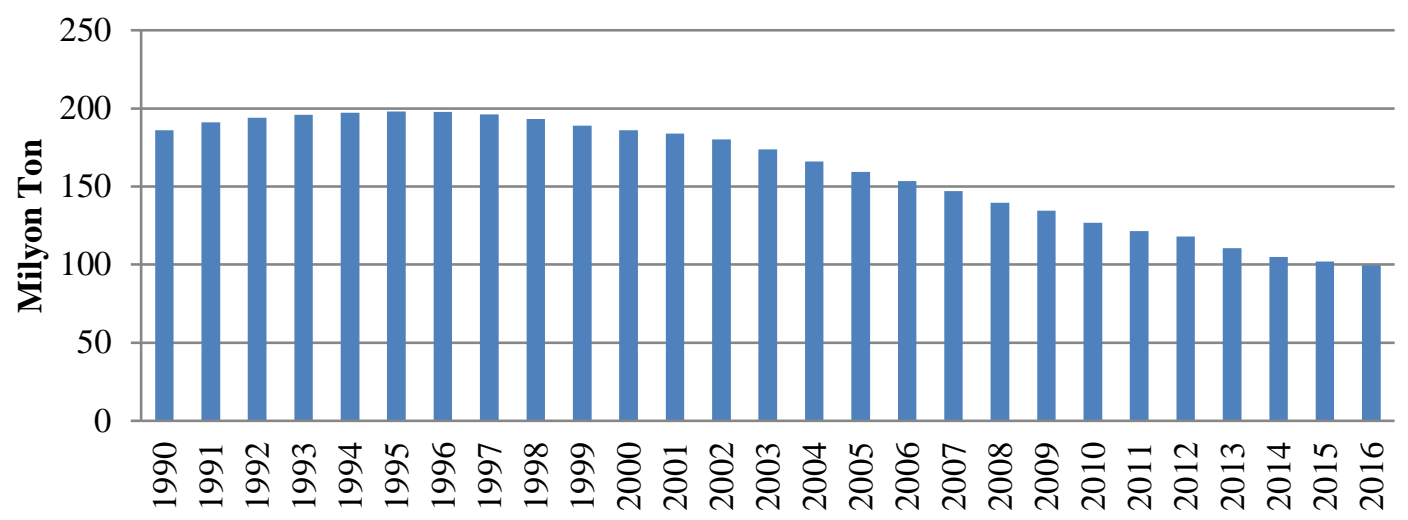

Şekil 3. AB'ne üye ülkelerde katı atık yönetiminden meydana gelen sera gazı emisyon miktarları

Yine aynı kaynakta Türkiye'de 1990-2016 yılları arasında katı atıklardan meydana gelen sera gazlarının miktarları da Şekil 4'te verilmektedir [36].

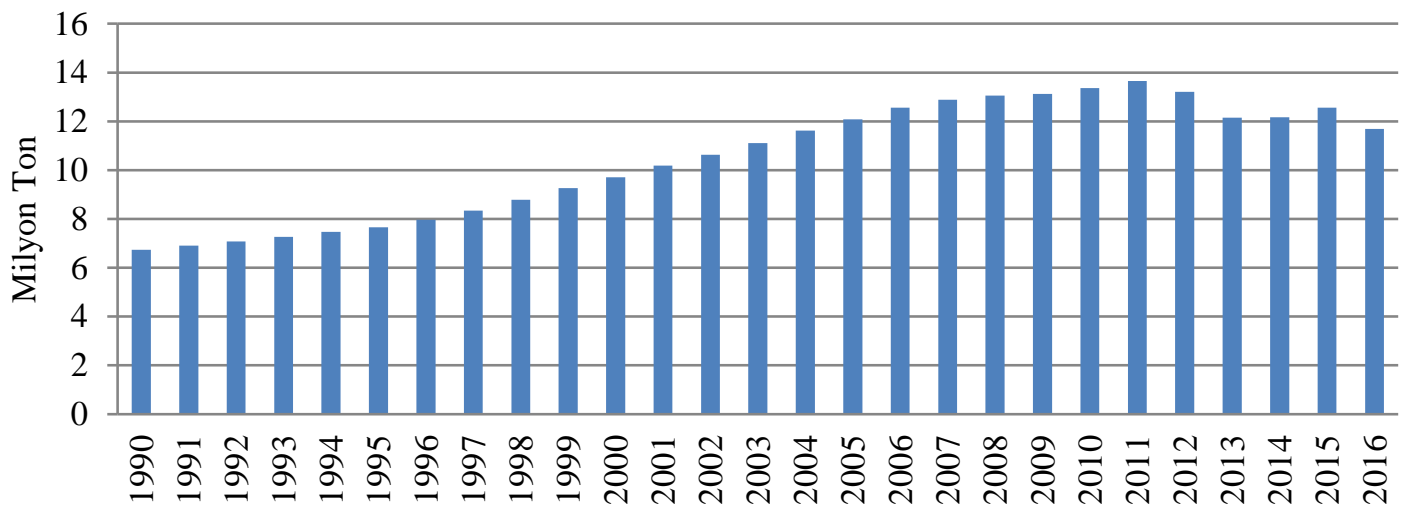

Şekil 4. Türkiye'de katı atık yönetiminden meydana gelen sera gazı emisyon miktarları

Şekil 3 ve 4 incelendiklerinde AB üyesi ülkelerde 2016 yılına doğru gelindikçe katı atık yönetiminden kaynaklı sera gazlarının azaldığı buna karşı; ülkemizde ise arttığı görülmektedir.

Kentsel atık miktarları ile fiziksel ve kimyasal özellikleri, ülke, şehir ve hatta mevsimlere göre değişiklik gösterebilmektedir. Atık miktarları düşük gelirli ülkelerde 0,1-0,5 ton/kişi/yıl, orta gelirli ülkelerde 0,20,6 ton/kişi/y1l, yüksek gelirli ülkelerde ise $0,3-0,8$ ton/kişi/yıl olarak gözlemlenmiştir. Gelişmiş ülkelerde atık yönetiminin her safhasında geri dönüşüm bulunmakta; bu nedenle çok az miktarı depolama tesislerinde bertaraf edilmektedir. Ancak düşük gelirli ülkelerde ekonomik büyüme, hayat şartları ve konumlarının güçlüğü nedeniyle gelişmiş bertaraf etme yöntemlerinin uygulanmasında güçlük çekilmektedir [25]. Bu durum ise atıklardan meydana gelen sera gazı emisyonlarını düşük ve orta gelirli ülkelerde arttırmaktadır.

\section{A. SERA GAZI OLUŞUMU}

Özellikle kentsel atıkların bünyesinde yiyecek, kâğıt, ahşap, bahçe atıkları gibi organik maddeler bulunmaktadır. Bu atıklar depolama tesislerine götürüldüklerinde, atıkların içerisinde bulunan karbonlar bakteriler tarafindan tüketilmeye başlanmaktadır. Ayrıca depolama alanlarındaki anaerobik koşullar metan üretici bakterilerin gelişmesine neden olmaktadır. Bu bakteriler nedeniyle organik maddeler parçalanır ve deponi gazı adı verilen metan (yaklaşı \% 50 ), $\mathrm{CO}_{2}$ (yaklaşı $\% 50$ ) ve eser miktarda diğer gazlar ( $<\% 1$, hidrojen, su buharı, $\mathrm{H}_{2} \mathrm{~S}, \mathrm{NH}_{3}$ aromatikler, klorlu organik bileşikler ve UOB)'dan oluşan bir gaz meydana gelmektedir $[26,37,38]$. Karbon olmayan sera gazlarından olan $\mathrm{N}_{2} \mathrm{O}$ ise yine atık 
yönetiminden meydana gelen bir gazdır. Ancak bu gazın daha çok atık taşımacılığından kaynaklandığ 1 belirtilmekte ve miktarının yük ile mesafeye bağlı olarak değiştiği görülmektedir [29]. Ayrıca atık yönetiminde kullanılan iş makinelerinden de sera gazı emisyonları oluşmakta ve dizel yakıtlı bir motorun yaklaşık olarak $2,7 \mathrm{~kg} \mathrm{CO} / \mathrm{L}$ emisyona neden olduğu literatürdeki çalışmalarda görülmektedir [28].

Depolama alanlarındaki biyokütlenin ortalama molekül yapısı $\mathrm{C}_{6} \mathrm{H}_{10} \mathrm{O}_{4}$ olarak söylenebilir. Üretilen metanın büyük bir kısmı bu kütlenin anaerobik ortamda parçalanmasıyla meydana gelmektedir. Eşt. 1' de ise bu reaksiyon süreci verilmektedir [39]

$$
\mathrm{C}_{6} \mathrm{H}_{10} \mathrm{O}_{4}+1,5 \mathrm{H}_{2} \mathrm{O} \rightarrow 3,25 \mathrm{CH}_{4}+2,75 \mathrm{CO}_{2}
$$

Depolama alanlarında oluşan gazların bileşenleri atık bileşenleri ile orantılı olarak değişmektedir. Ayrıca depolama alanlarında meydana gelen sera gazı oluşumları ve miktarları depolama alanının yaşına, atık kompozisyonuna, nem, partikül çapı, $\mathrm{pH}$, sıcaklık, deponi tasarımı ve işletilmesi gibi birçok faktöre bağlı olarak değişiklik göstermektedir [40]. Tüm bunlara göre Tablo 2' de verilen sekiz adet faz bulunmaktadır.

Yine depolama alanlarında işletilen yerler kapalı olanlara nazaran daha fazla sera gazı emisyonu oluşturmaktadır. Ancak kapatılan alanlar birkaç sene daha sera gazı yaymaya devam etmektedirler [27]. Bazı kaynaklarda deponi alanlarının 30 seneye kadar sera gazlarını üretebildiği belirtilmektedir [41].

Tablo 2. Deponi gazlarının oluşum süreçleri [29]

\begin{tabular}{|c|c|c|}
\hline $\mathrm{Faz}$ & Tanımı & Özellik \\
\hline 1 & Anaerobik faz & $\begin{array}{l}\text { Sicaklık ve nem gibi yerel faktörlere bağlı olarak birkaç günden } \\
\text { birkaç aya kadar sürmektedir. }\end{array}$ \\
\hline 2 & Asidik faz & $\begin{array}{l}\text { Fakültatif ve fermantatif anaerobik bakterilerin popülasyonu } \\
\text { artmaktadır. Meydana gelen uçucu yağ asitleri, } \mathrm{CO}_{2} \text { ve } \mathrm{H}_{2} \text {, atıktaki } \\
\mathrm{N}_{2} \text { ile yer değiştirirler. Koşullara bağlı olarak birkaç hafta ile y1l } \\
\text { sürebilmektedir. }\end{array}$ \\
\hline 3 & $\begin{array}{l}\text { Metanojenik faz } \\
\text { başlangicı }\end{array}$ & $\begin{array}{l}\text { Bakteriyel solunum } \mathrm{O}_{2}^{\prime} \text { yi tüketmiştir ve metajonik bakteriler } \\
\text { çoğalmaya başlamıştır. } \mathrm{CO}_{2} \text { ve } \mathrm{H}_{2} \text { konsantrasyonları düşmeye } \\
\text { başlamışıtır. }\end{array}$ \\
\hline 4 & $\begin{array}{l}\text { Kararlı metanojenik } \\
\text { faz }\end{array}$ & $\begin{array}{l}\text { Kalan } \mathrm{H}_{2}, \mathrm{CO}_{2} \text { indirgemesinde kullanılır } \mathrm{CH}_{4} \text { ve } \mathrm{H}_{2} \mathrm{O} \text { meydana gelir. } \\
\text { Bu fazda toplanan tipik bir deponi gazının hacimce \% 40- } 65 \text { 'i } \mathrm{CH}_{4} \\
\text { 'tür. }\end{array}$ \\
\hline 5 & Hava girişi & $\begin{array}{l}\text { Metanojenik aktivitenin kinetiği besinlerin azalmasıyla } \\
\text { yavaşlamıştır. Sonuç olarak atığa hava girişi başlamıştır. }\end{array}$ \\
\hline 6 & Metan oksidasyonu & $\begin{array}{l}\text { Metanojenlerin oranı düşmektedir, hava girişi başlamıştır ve deponi } \\
\text { aerobik koşullara dönmüştür. }\end{array}$ \\
\hline 7 & $\mathrm{CO}_{2}$ faz1 & $\begin{array}{l}\text { Aerobik koşullara dönülmüştür. Deponi gazı oluşumu substrat } \\
\text { sınırlaması nedeniyle neredeyse bitmiştir. Dayanıklı katı organik } \\
\text { maddelerin aerobik bozuşması başlamıştır. }\end{array}$ \\
\hline 8 & Toprak hava fazı & $\begin{array}{l}\text { Dayanıklı organik maddelerin tamamının oksitlendiği faz olup son } \\
\text { faz olarak nitelenmektedir. }\end{array}$ \\
\hline
\end{tabular}

\section{B. DEPOLAMA ALANLARINDA SERA GAZLARI MODELLEME YAKLAŞIMLARI}

Literatüre bakıldığında bir ton kentsel atıktan yaklaşık olarak $40-250 \mathrm{~m}^{3}$ sera gazı meydana geldiği belirtilmiştir $[42,25]$. Vahşi depolama alanlarında ise 1 ton atıktan yaklaşık olarak $300 \mathrm{~kg} \mathrm{CO}_{2}$ eşdeğeri sera gazı, düşük organik içerikli atıklardan ise $70 \mathrm{~kg} \mathrm{CO}$-eş/ton sera gazı yayıldı bulunan araştırmalarda görülmüştür [28]. Atıklardan meydana gelecek metan gazlarının hesaplanmasında ise aşağıda verilen faktörler göz önünde bulundurulur [43]:

- Toplanılan atıkların organik madde içeriği ve kalitesi, 
- Atıklardaki parçalanabilir madde miktarı,

- Metan çevrim fonksiyonu,

- Karbondan metana dönüş faktörü,

- Atıkların depolama alanında toplanma oranı ile parçalanma oranı,

- Alanlardaki gaz toplama sistemi,

- Metan düzeltme faktörü

Tüm bunlar ele alındığında IPCC'ye göre $1 \mathrm{~kg}$ organik atıktan $4 \mathrm{gr} \mathrm{CH}_{4}$ meydana geldiği rapor edilmiştir [43]. Yapılan çalışmalar incelendiğinde atık yönetimi sırasında özellikle depolama alanlarında meydana gelebilecek gaz emisyonlarının modellenebilmesi için çeşitli yöntemlerin kullanıldığ belirlenmiştir.

\section{B. 1. Stokiometrik Model}

Bu model atıkların stokiometrik reaksiyonlarına dayanmaktadır.

$$
\mathrm{C}_{a} \mathrm{H}_{b} \mathrm{O}_{c} \mathrm{~N}_{d}+n \mathrm{H}_{2} \mathrm{O} \rightarrow x \mathrm{CH}_{4}+y \mathrm{CO}_{2}+w \mathrm{NH}_{3}+z \mathrm{C}_{5} \mathrm{H}_{7} \mathrm{O}_{2} \mathrm{~N}+\text { Enerji }
$$

Bu modelde parçalanamayan atıklar (plastik cam vb.), nem ve toksisite oldukça sınırlayıcıdır [27].

\section{B. 2. Zero-Order Modeli}

Zero-Order Modelinde deponi alanlarında üretilen gaz emisyonları zamana karşı kararlı olduğu varsayılmaktadır. Yani atık yaşı ve tipi gaz üretimi üzerindeki etkileri önemsizdir [44].

$$
Q=\frac{\left(m x L_{0}\right)}{\left(t_{0}-t_{f}\right)} \quad t_{0}<t<t_{f}
$$

Burada;

$\mathrm{Q} \quad$ : Metan üretim oranı (hacim/zaman)

M : Atığın kütlesi

$\mathrm{L}_{0}:$ : Metan üretim potansiyeli

$\mathrm{t}:$ Zaman

$\mathrm{t}_{0} \quad:$ Gecikme zamanı

$\mathrm{t}_{\mathrm{f}} \quad: \quad$ Üretimin bitiş zamanıdır

\section{B. 3. LandGEM Emisyon Modeli}

EPA tarafından geliştirilen kullanımı basit bir parçalanma eşitliğine dayanan bu modelde gaz emisyonları tahmin edilebilmektedir. Metan üretim kapasitesi ile depolanan atık kütlesi kullanılarak metan üretimini tahmin edilebilmektedir [45].

$$
Q_{\text {emisyon }}=\sum_{i=1}^{n} \sum_{J=0,1}^{1} k L_{0}\left(\frac{M_{i}}{10}\right)\left(e^{-k t}\right)
$$

Burada;

$\mathrm{Q}_{\mathrm{CH} 4}:$ Y 1 ll1k meydana gelen metan miktar1 $\left(\mathrm{m}^{3} / \mathrm{y} 1 \mathrm{l}\right)$

i : Y Y1 artımı

n $\quad$ : Hesaplama yıll1-atığın boşaltıldığ ilk yıl

y : Yillik 0,1 artım

$\mathrm{k} \quad$ : Metan oluşum sabiti (1/y1l)

$\mathrm{L}_{\mathrm{o}} \quad$ : Metan oluşum kapasitesi $\left(\mathrm{m}^{3} / \mathrm{mg}\right)$

mi : i. yıldaki atık miktarı $(\mathrm{mg})$ 
$\mathrm{CO}_{2}$ emisyonu ise Eşt. 5'teki gibi hesaplanmaktadır [27].

$$
Q_{c}=\frac{\left(Q_{m} \times C_{c} \times M_{c}\right)}{\left(1 \times 10^{6} \times 2,41\right)}
$$

Yukarıdaki eșitlikte;

$\mathrm{Q}_{\mathrm{m}} \quad$ : Metan oluşum miktarı $\left(\mathrm{m}^{3} / \mathrm{y} 1 \mathrm{l}\right)$

$\mathrm{C}_{\mathrm{c}} \quad$ : Karbon bileşiği konsantrasyonu ( ppmV)

$\mathrm{M}_{\mathrm{c}} \quad$ : Karbon bileşiğinin moleküler ağırlığı

$1 \times 10^{6}$ : Çeviri faktörü (ppmV)

22,41 : Gaz sabiti

\section{B. 4. Tabasaran \& Rettenberger Modeli}

Tabasaran\&Rettenberger modeli, organik karbon içeren atıkların biyodegredasyonunu belli bir zaman dilimi içerisinde birinci dereceden parçalanma yaklaşımına benzeterek ifade etmekte ve oluşan gaz miktarını teorik olarak açıklayabilmektedir [46];

Model Eşt. 6' da verilmektedir.

$$
G_{t}=1,868 x C_{\text {org }}(0,014 x T+0,28) x\left(1-10^{-k t}\right) x M_{t}
$$

Burada;

$\mathrm{T} \quad$ : Sicaklık $\left({ }^{\circ} \mathrm{C}\right)$

$\mathrm{C}_{\text {org }}:$ Atığın organik karbon miktarı $\left(\mathrm{kg}{ }^{\circ} \mathrm{C} /\right.$ Ton atık)

$\mathrm{k} \quad$ : Bozunma sabiti $\left(\mathrm{y}^{-1}\right)$

$\mathrm{M}_{\mathrm{t}} \quad$ : t yılındaki atığın miktarı

$\mathrm{G}_{\mathrm{t}} \quad: \quad \mathrm{t}$ yılındaki toplam deponi gazı üretimi $\left(\mathrm{m}^{3}\right)$

Model parametreleri olarak, $25-40{ }^{\circ} \mathrm{C}^{\prime} \mathrm{de} 170-220 \mathrm{~kg}$ organik karbon/ton olduğu ve metan üretim oranının 0,025-0,050 $\mathrm{y}^{-1}$ olduğu önerilmektedir [46].

\section{B. 5. Scholl Canyon Modeli}

Scholl Canyon modeli metan gazı oluşumundaki tepkimelerin birinci ve ikinci aşamalarını dikkate almamaktadır. Ayrıca model zaman gecikmesi aşaması ile sınırlayıcı faktörleri hesaba katmamaktadır [44, 47]. Toplam meydana gelen metan miktarı Eşt. 7'deki gibi hesaplanmaktadır [48].

Burada,

$$
Q=\sum_{i=1}^{n} r_{i} k_{i} L_{o i} e^{-k_{i} t_{i}}
$$

Q : Hesaplanan yıldaki metan üretim oranı

$\mathrm{n} \quad$ : Atık depolamaya başlandıktan itibaren geçen yıl

$\mathrm{r}_{\mathrm{i}} \quad$ : i yılındaki atık miktarı

$\mathrm{k}_{\mathrm{i}} \quad$ : i yılındaki gaz üretim oranı

$\mathrm{L}_{\mathrm{oi}}: \mathrm{t}=0$ ' daki atık miktarından üretilen metan hacmi

$\mathrm{t}_{\mathrm{i}} \quad$ : $\quad \mathrm{i}$ yılındaki atığın yaşı 


\section{B. 6. IPCC Standart Metodu}

IPCC standart modeli basit kütle balansı eşitliğine dayanmakta olup, atık depolama sitesinden meydana gelen metan miktarını hesaplamaktadır. Bu hesaplamada aynı yıldaki tüm atıkların bozularak metan saldığa farz edilmektedir [48].

$$
\mathrm{CH}_{4}\left(\frac{G g}{y l l}\right)=\left(\frac{M S W_{t} \times M S W_{F} x M C F \times D O C \times D O C_{F} x F \times 16}{12}-R\right) x(1-O X)
$$

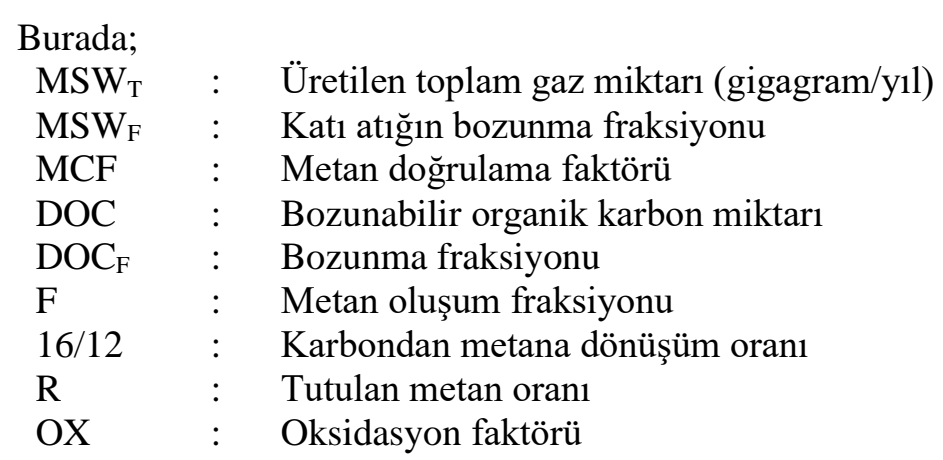

Bu model diğerleri ile karşılaştırıldığında girilen parametrelerin sınırlı olması nedeniyle biraz daha basit olmaktadır [48].

\section{B. 7. TNO Modeli}

Atıkların bozunması birinci dereceden bir modelde hesaplanmakta ve deponi gazı oluşumunun zamana göre katlanarak azaldığı varsayılmaktadır. Eşitlikte atıklardaki karbon ve bozulma oranı dikkate alınmaktadır. Matematiksel olarak Eşt. 9'daki gibi tanımlanabilir [49, 50]:

$$
G_{t}=d x 1,87 x A x C_{o} x k_{1} x e^{-k t}
$$

Burada;

$\begin{array}{lll}\mathrm{Gt} & : & \text { Deponi gazı üretim miktarı }\left(\mathrm{m}^{3} / \mathrm{y} 1 \mathrm{l}\right) \\ \mathrm{d} & : & \text { Bozunma faktörü }(0,58) \\ \mathrm{A} & : & \text { Alandaki atık miktarı }\left(\mathrm{m}^{3} / \mathrm{kg} \mathrm{C}\right) \\ \mathrm{C}_{\mathrm{o}} & : & \text { Atıktaki karbon miktarı }(\mathrm{kg} \mathrm{C} \text { atık} / \mathrm{mg} \text { atık }) \\ \mathrm{k} & : & \text { Parçalanma sabiti }(0,094)\end{array}$

\section{B. 8. Çoklu Faz Modeli (Afvalzorg)}

Farklı atık türleri farklı oranlarda bozunabilen organik madde içermektedir. Çok fazlı modellemenin avantajı, çoklu atık bileşiminin dikkate alınabilmesidir. Afvalzorg çok fazlı modelde, sekiz adet atık kategorisi ve ayırt edici üç fraksiyon bulunmaktadır. Deponi gazı her fraksiyon için ayrı olarak hesaplanir [51].

$$
\alpha_{t}=\varsigma \sum_{i=1}^{3} c A C_{0, i} k_{1, i} e^{-k_{1, i} t}
$$

\footnotetext{
Burada;

$\alpha_{\mathrm{t}} \quad$ : Deponi gazı oluşum miktarı $\left(\mathrm{m}^{3}\right.$ gaz/yıl $)$

$\varsigma \quad$ : Parçalanma faktörü

$\mathrm{i}$ : Parçalanma oranlı atık fraksiyonu $\mathrm{k}_{1, \mathrm{i}}\left[\mathrm{kg}_{\mathrm{i}} \mathrm{kg}_{\text {waste }}{ }^{-1}\right]$

c : Dönüşüm faktörü $\left[\mathrm{m}^{3}\right.$ gazkgOM $^{-1}$ parçalanma $]$
} 
A : Atık miktarı $[\mathrm{Mg}]$

Co : Atığın organik madde miktarı $\left[\mathrm{kgOM} \mathrm{Mg}\right.$ waste $\left.^{-1}\right]$

$\mathrm{K}_{1, \mathrm{i}}$ : Parçalanma sabiti [1/y11]

t : Deponi işleminin başlamasından beri geçen süre

\section{B. 9. EPER Modeli Fransa}

Fransa EPER modeli metan emisyonlarını tahmin etmek için iki farklı yaklaşım kullanmaktadır. Bu iki yaklaşım [50];

1-Deponi alanlarında meydana gelen ve metan gazının toplanarak kullanılan sistemler.

2-Deponi alanlarında meydana gelen ve metan gazının kullanılmadığı, geleneksel çok fazlı model.

Metan gazlarının toplanarak kullanıldığı sistemlerde oluşan gaz miktarı Eşt. 11'deki gibi hesaplanmaktadır [50]:

$$
A=\mathrm{FxH} x\left[\mathrm{CH}_{4}\right]
$$

Burada;

$\begin{array}{lll}\mathrm{A} & : & \text { Tutulan deponi gazı miktarı } \\ \mathrm{F} & : & \text { Deponi gazı ekstraksiyon oranı } \\ \mathrm{H} & : & \text { Y1llık sıkıştırma işlemi } \\ {\left[\mathrm{CH}_{4}\right]} & : & \text { Deponi gazındaki metan konsantrasyonu }\end{array}$

Geri kazanım sistemi kullanılmayan deponilerde meydana gelen gaz miktarları ise Eşt. 12'deki gibi hesaplanmaktadır [50]:

$$
F E_{C H_{4}}=\sum_{x} F E_{0} x\left(\sum_{1,2,3} A_{i} x p_{i} x k_{i} x e^{-k_{i} t}\right)
$$

Burada;

$\mathrm{FE}_{\mathrm{CH} 4}:$ Y1llık metan üretimi $\left(\mathrm{Nm}^{3} \mathrm{y}^{-1}\right)$

$\mathrm{FE}_{0} \quad$ : Deponi gazı üretim potansiyeli $\left(\mathrm{m}^{3} \mathrm{CH}_{4}\right.$ ton atık $\left.{ }^{-1}\right)$

$\mathrm{P}_{\mathrm{i}} \quad: \quad \mathrm{k}_{\mathrm{i}}$ bozunma oranlı atık fraksiyonu $\left(\mathrm{kg}_{\mathrm{i}} \mathrm{kg}_{\mathrm{attk}}{ }^{-1}\right)$

$\mathrm{k}_{\mathrm{i}} \quad$ : i fraksiyonundaki bozunma oran $1\left(\mathrm{y}^{-1}\right)$

$\mathrm{t} \quad:$ Atığın yaşı $(\mathrm{y}$ 1l)

$\mathrm{A}_{\mathrm{i}} \quad$ : Normalizasyon faktörü (-)

\section{B. 10. EPER Modeli Almanya}

Almanya'da kullanılan EPER modeli ise Eşt. 13 ile ifade edilmiştir [50].

$$
M e=M x B D C x B D C_{f} x F x D x C
$$

Bu eşitlikte;

$\mathrm{Me} \quad$ : Çıkan emisyon miktarı $\left(\mathrm{Mg} \cdot \mathrm{y}^{-1}\right)$

M : Yillı olarak depolanan atık miktarı $(\mathrm{Mg})$

BDC : Karbon bozunma oranı (MgC.Mg Atık $\left.{ }^{-1}\right)$

$\mathrm{BDC}_{\mathrm{f}}$ : Deponi gazına dönüşen karbonun bozunma oranı

F : $\quad \mathrm{CH}_{4}$ e dönüş̧en karbonun hesaplanma faktörü (-)

D : Toplama verimi (aktif gaz gidermede bu değer 0,4 ; toplama sistemi yoksa 0,9 alınmalıdır)

$\mathrm{C}: \mathrm{CH}_{4}(\%)$ 


\section{KATI ATIKLARIN KOMPOST ISSLEMLERINNDEN MEYDANA GELEN SERA GAZI EMISYONLARI VE MODELLEME YAKLAŞIMLARI}

Kompostlama işlemi, özellikle organik karakterli atıkların bertaraf edilmesi işleminde oldukça çevreci bir yaklaşımdır. Kompostlama işleminin faydaları olmasına rağmen, işlem boyunca sera gazları meydana gelmekte ve atmosfere karışabilmektedir [52]. Genel olarak atıkların kompostlama işlemi, aerobik bir süreçtir ancak yine de $\mathrm{CH}_{4}$ emisyonları meydana gelebilmektedir. Bu süreç ise kompost yığınlarının içerisinde bulunan anaerobik ortamlarda oluşmaktadır. Sözü edilen süreç ise Eşt. 14 ile ifade edilmektedir [53]

$$
\mathrm{CH}_{4}=(\mathrm{W} \times \mathrm{DOC} \times E F) \times 10^{-3}-\mathrm{R}
$$

Bu eşitlikte;

$\mathrm{CH}_{4}$ : Kompost işleminde meydana gelen toplam $\mathrm{CH}_{4}$ emisyonu $\left(\mathrm{GgCH}_{4} \mathrm{y}^{-1}\right)$

W : Kompostlanan atık miktarı $\left(\mathrm{Ggy}^{-1}\right)$

DOC : Bozunabilir organik karbon

EF : Kompostlama işleminin emisyon faktörü $\left(4,0 \mathrm{gCH}_{4} \mathrm{~kg}^{-1}\right.$ atık)

$\mathrm{R} \quad$ : Geri kazanılan $\mathrm{CH}_{4}$ ün toplam kütlesidir

Arıca kompostlama işlemlerinde nitrifikasyon ve denitrifikasyon süreçlerinde $\mathrm{N}_{2} \mathrm{O}$ emisyonları da oluşturmaktadır [54]. Bu süreç de Eşt. 15 ile ifade edilmektedir [53]:

$$
\mathrm{N}_{2} \mathrm{O}=(W x D O C x E F) \times 10^{-3}-\mathrm{R}
$$

Burada;

$\mathrm{N}_{2} \mathrm{O}$ : Kompost işleminde meydana gelen toplam $\mathrm{N}_{2} \mathrm{O}$ emisyonu $\left(\mathrm{GgN}_{2} \mathrm{Oy}^{-1}\right)$

EF : Kompostlama işleminin emisyon faktörü $\left(0,3 \mathrm{~g} \mathrm{~N}_{2} \mathrm{O} \mathrm{kg}{ }^{-1}\right.$ atık$)$

EPA tarafindan yayınlanan raporlarda ise kompostlama işlemlerinden meydana gelen kaçak emisyonlarda metan gazı $0,0055 \mathrm{MTCO}_{2} \mathrm{E} /$ ton ve $\mathrm{N}_{2} \mathrm{O}$ gazı $0,0396 \mathrm{MTCO}_{2} \mathrm{E} /$ ton olarak verilmektedir [55].

\section{YAKMA TESISLERINDEN KAYNAKLI SERA GAZI EMISYONLARI VE MODELLEME YAKLAŞIMLARI}

Atık yakma tesisleri katı atıkların kontrollü bir şekilde bertaraf edildiği yerler olarak tanımlanmaktadır. Atıkların yakılmasından oluşan sera gazı yılda yaklaşık olarak 40106 ton $\mathrm{CO}_{2}$ 'ye eşdeğer miktarındadır ve bu da depolama alanlarından kaynaklanan emisyonların onda biri kadardır. Yanma işleminden oluşan $\mathrm{CO}_{2}$ miktarı atıkların karbon bileşimine bağlı olarak Eşt. 16' daki gibi hesaplanabilmektedir [53, 56]:

$$
C O_{2}=W x \sum_{j}\left(W F_{j} x d m_{j} x F C F_{j} x O F_{j}\right) x \frac{44}{12}
$$

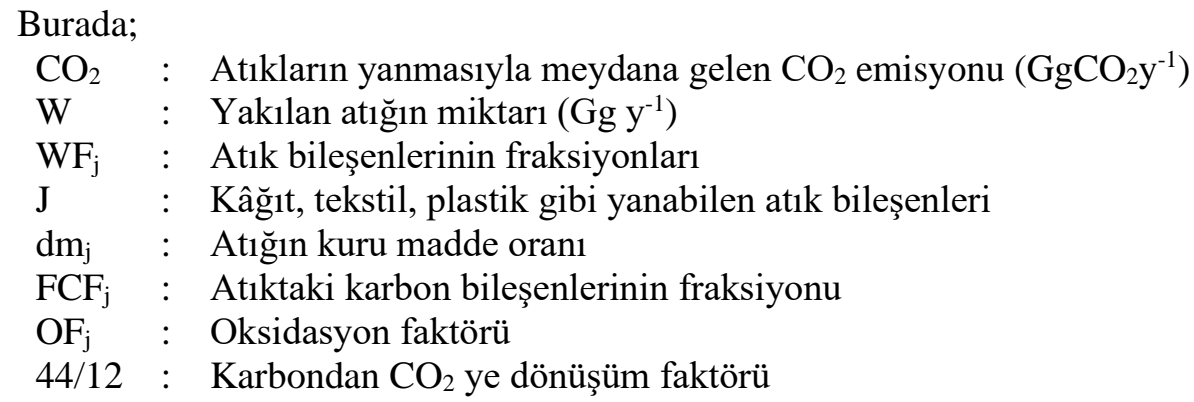

Yakma tesislerinden meydana gelen $\mathrm{N}_{2} \mathrm{O}$ miktarı ise Eşt. 17'deki gibi hesaplanabilmektedir [53]. 
$N_{2} O_{=} \sum_{j}\left(I W_{i} x E F_{i}\right) \times 10^{-6}$

Bu eşitlikte;

$\mathrm{N}_{2} \mathrm{O}$ : Atıkların yanmasıly meydana gelen $\mathrm{N}_{2} \mathrm{O}$ emisyonu $\left(\mathrm{Gg} \mathrm{N}_{2} \mathrm{O} \mathrm{y}^{-1}\right)$

$\mathrm{IW}_{\mathrm{i}}$ : Yakılan atı̆̆ın miktarı $\left(\mathrm{Gg} \mathrm{y}^{-1}\right)$

$\mathrm{EF}_{\mathrm{i}}$ : Emisyon faktörü (47 $\mathrm{kg} \mathrm{N}_{2} \mathrm{O} \mathrm{Gg}^{-1}$ atık)

Atık yakma tesislerinden meydana gelen $\mathrm{CH}_{4}$ emisyonları ise Eşt. 18'deki gibi ifade edilmektedir [53].

$$
C H_{4 \text { Emisyonu }}=\sum_{j}\left(I W_{i} x E F_{i}\right) \times 10^{-6}
$$

Bu eşitlikte ise;

$\mathrm{CH}_{4}$ : Atıkların yanmasiyla meydana gelen $\mathrm{CH}_{4}$ emisyonu $\left(\mathrm{Gg} \mathrm{CH}_{4} \mathrm{y}^{-1}\right)$

$\mathrm{IW}_{\mathrm{i}}$ : Yakılan atı̆̆ın miktarı $\left(\mathrm{Gg} \mathrm{y}^{-1}\right)$

$\mathrm{EF}_{\mathrm{i}} \quad$ : Emisyon faktörü (200 $\mathrm{kg} \mathrm{CH}_{4} \mathrm{Gg}^{-1}$ atık)

\section{KATI ATIK YÖNETIMINDE SERA GAZI AZALTIMI}

Özellikle deponi alanlarındaki sera gazı emisyonlarının azaltılabilmesi için öncelikle atık içeriğindeki karbon oranının azaltılması gerekmektedir. Bunun için ise atık yakma, gazifikasyon gibi farklı bertaraf edilme yöntemleri uygulanmalıdır. Bir diğer yöntem ise atıklarda bulunan besin, kâğıt, karton gibi organik içerikli maddelerin ayrıştırılmasıdır [57]. Depolama sahaları ve vahşi depolama alanlarından kaynaklanan metan gazı konsantrasyonunun azaltılması için iki yaklaşım bulunmaktadır. Bunlardan ilki atık kütlesine inşa edilmiş gaz toplama borularından gazın çekilerek yakılması, ikincisi ise organik atıkların azaltılarak gelecekte daha az metan oluşumunun sağlanmasıdır. Gaz toplama sistemlerinin avantajı toplanan gazın enerji olarak kullanılabilmesidir. Bu sebeple aşağıdaki yöntemler kullanılmaktadır [58]:

Gazın doğrudan kullanımı; Orta kalitedeki gaz yakıt olarak kullanılmakta, alternatif bir enerji kaynağı olmaktadır [58].

Elektrik üretimi; Toplanılan gaz sistemde bulunan elektrik jeneratörünü çalıştırmakta kullanılmaktadır [58].

Buhar Üretimi; Elde edilen gaz yakılarak buhar elde edilir ve 1sıtma veya diğer işlemler için kullanılmaktadır [58].

Yakma; $\mathrm{Bu}$ yöntemde toplanılan gaz atmosfere verilmeden önce yakılmaktadır. Yakma işlemi için gerekli yatırım maliyetleri diğer yöntemlere nazaran oldukça düşüktür. Ancak herhangi bir enerji eldesi söz konusu değildir [58].

Kompostlama işleminden meydana gelebilecek sera gazı emisyonlarında ise katı atıkların bileşiminin etkisi oldukça kritiktir. Bunun yanında atığın yüksek nem içeriği ve yoğunluğu daha yüksek sera gazı miktarı ile ilişkilendirilmektedir. Atıkta bulunan aşırı su atığın serbest hava boşluklarını azaltır ve anaerobik ortam oluşturur. $\mathrm{Bu}$ nedenle atı̆̆ın doğru nem miktarı sera gazı oluşumunu engelleyebilmektedir. Ayrıca atık yığınının doğal veya yapay yollardan havalandırılması anaerobik 
şartları önlemektedir [52]. Atıkların yakılarak bertaraf edildiği tesislerde sera gazı azaltımında özellikle $\mathrm{CO}_{2}$ ile $\mathrm{N}_{2} \mathrm{O}$ gazının kontrol edilmesi gerekmektedir. Baca gazı arıtımı kullanarak $\mathrm{CO}_{2}$ emisyonların kontrol edilebilmektedir. Baca gazlarındaki $\mathrm{CO}_{2}$ 'nin $\mathrm{NaOH}$ ile reaksiyona sokulmasıyla sodyum karbonat üretimi mümkündür. $\mathrm{N}_{2} \mathrm{O}$ emisyonunun azaltılmasında ise yakma sıcaklıklarının ayarlanması oldukça önemlidir. $\mathrm{N}_{2} \mathrm{O}$ genelde $850^{\circ} \mathrm{C}$ ' nin altındaki sıcaklıklarda ve oksijen miktarının yetersiz olduğu durumlarda meydana gelmektedir. Özellikle $\mathrm{NO}_{x}$ ve $\mathrm{N}_{2} \mathrm{O}$ gibi emisyonların en düşük oranda oluşacağ 1 sıcaklık aralığ $1850-900{ }^{\circ} \mathrm{C}$ ' dir. $900{ }^{\circ} \mathrm{C}$ ' nin üzerindeki sıcaklılarda da $\mathrm{N}_{2} \mathrm{O}$ oranının düştüğü rapor edilmektedir [59].

\section{TARTISMA ve SONUC}

Katı atıklar önemli çevre sorunlarından bir tanesidir. Özellikle yoğun kentleşme sonucunda meydana gelen atıkların yönetimi yani toplanmasından bertaraf edilmesine kadar olan süreç bir hayli zor ve masraflı olmaktadır. Tüm bu süreç içerisinde çevreye en az zararı veren yöntemlerin kullanılması esastır. Atık yönetimi sonucunda her yıl oldukça fazla sera gazı atmosfere salınmaktadır. Literatürdeki çalışmalar incelendiğinde atıkların toplanması ve taşınması sırasında bile atmosfere sera gazlarının salındığ 1 anlaşılmıştır. Atık bertaraf etme yöntemleri olan düzenli depolama, kompostlama ve yakma işlemleri atık yönetiminde oluşan sera gazlarının önemli kaynaklarındandır. Özellikle bertaraf etme işlemlerinde oluşabilecek sera gazlarının modellenmesi hem enerji potansiyelinin tahmininde hem de sera gazı miktarının belirlenmesinde önemlidir. Tüm bunların yanında belediye atıklarının kompozisyonu da bilinmelidir. Böylelikle atığın nem ve organik madde içeriği bilinebilir ve oluşacak sera gazı tahmin edilebilecektir.

Atık yönetim sistemlerinin seçimi sera gazlarını önlemede büyük bir role sahiptir. Kentsel atıkların kaynağında ayrıştırılması sera gazı emisyonlarını azaltacaktır. Özellikle organik atıkların ayrı toplanması ve bunlardan kompost eldesi önemli miktardaki sera gazı emisyonunu atmosfere karışmadan durduracaktır. Yakma tesislerindeki teknolojilerin iyileştirilmesi de bir diğer tedbirlerdendir. Bunun yanı sıra deponi alanlarındaki gazların toplanması ve bunlardan enerji üretimi de hem enerji ihtiyacının bir kısmını karşılayacak hem de emisyonları azaltacaktır. Ülkemize bakıldığında; 2016 yılı itibariyle 76 adet düzenli depolama sahası olmasına rağmen bu depolama sahalarının \%33'ünde enerji üretimi yapılmaktadır. İstanbul'da 3, Ankara'da 2, Adana, Bursa, Kayseri, Konya, Gaziantep, Kocaeli, Elazığ, Hatay, Trabzon, Malatya, Antalya, Tokat, Aksaray, Uşak, Amasya, Bolu, Kırıkkale ve Denizli illerinde birer adet olmak üzere toplamda 25 adet sahada deponi gazından elektrik üretilmektedir [60]. Bu çalışmaların tüm illere yayılması ile emisyon azaltımı ve enerji kazanımı elde edilebilecektir.

Yapılan bu çalışmada atık bertaraf yöntemleri ile meydana gelebilecek sera gazlarının matematiksel olarak modellemesini sağlayan yöntemler araştırılmıştır. Literatür araştırması sonucunda modeller değerlendirildiğinde, Stokiometrik modelin atıkların parçalanma reaksiyonuna dayandığı görülmektedir. Zero-Order Modelinde özellikle deponi alanlarında meydana gelen gaz emisyonlarının zamana karşı kararlı olduğu varsayılmıştır. EPA tarafından geliştirilen LandGEM Emisyon Modeli ise basit parçalanma eşitliğine dayanmaktadır. Tabasaran \& Rettenberger Modelinde belli bir zaman diliminde organik karbon içeren atıkların birinci dereceden parçalanması söz konusudur. Scholl Canyon Modeli özellikle metan gazı oluşumunda rol alan tepkimelerin birinci ve ikinci aşamaları göz ardı edilmektedir. IPCC Standart Metodu ise basit kütle balansı eşitliğine dayanmaktadır. TNO Modelinde birinci dereceden hesap yapılmakta ve gaz emisyonlarının zamana göre katlanarak azaldığı varsayılmaktadır. Çoklu Faz Modeli (Afvalzorg) özellikle içeriği çok çeşitli olan atıkların parçalanmasında meydana gelen emisyonların hesaplanmasında kullanılmaktadır. EPER Modelinde deponi alanlarında meydana gelen gazları kullanan ile kullanmayan tesisler için iki farklı sistem geliştirilmiştir. Bunun yanında Ayrıca kompostlama ve yakma işlemleri sonucunda meydana gelebilecek emisyonları tahmin edebilecek yöntemler hakkında literatür araştırmalarına yer verilmiştir. Katı atıkların karakterizasyonu ve miktarı, bertaraf yöntemleri, iklim, gibi nedenlerden dolayı sera gazı emisyonları farkl1lık gösterebileceğinden Türkiye için matematiksel bir tahmin yöntemi oluşturulması 
gerekmektedir. Sonuç olarak elde edilen veriler ışı̆̆ında daha etkili bir sera gazı giderim sistemi tasarlanabilecektir.

\section{KAYNAKLAR}

[1] United Nations Framework Convention on Climate Change. (2019, 25 Şubat). Climate Change: Impacts, Vulnerabilities and Adaptation in Developing Countries. [Çevrimiçi]. Erişim: https://unfccc.int/resource/ docs / publications /impacts.pdf.

[2] N. Benson, Climate Change, Effects, Encyclopedia of Global Warming and Climate Change, California, USA: SAGE Publications, 2008.

[3] U.S. Environmental Protection Agency. (2019, 10 Mart). Climate change indicators in the united states. [Çevrimiçi]. Erişim: https://www.epa.gov/sites/production/files/201608/documents/Climate_indicators_2016.pdf.

[4] Nature Conservation Bureau, Ministry of the Environment, Government of Japan. (2019, 22 Şubat). Basic concept of climate change adaptation on biodiversity in Japan basic concept of climate change adaptation on biodiversity in Japan. [Çevrimiçi]. Erişim: https://www.env.go.jp/natüre/biodic/ kikou_tekiou-pamph/adaptation_en.pdf

[5] Intergovernmental Panel on Climate Change. (2019, 08 Nisan). Global warming of $1.5^{\circ} \mathrm{C}, \mathrm{An}$ IPCC Special Report on the impacts of global warming of $1.5^{\circ} \mathrm{C}$. [Çevrimiçi]. Erişim: https://report.ipcc.ch/sr15/pdf/sr15_spm_final.pdf

[6] U.S. Environmental Protection Agency. (2019, 08 Nisan). Overview of greenhouse gases. [Online]. Erişim: https://www.epa.gov/ghgemissions /overview-greenhouse-gases

[7] US National Academy of Sciences. (2019, 10 Şubat). Climate Change Evidence \& Causes. [Online]. Erişim: http://dels.nas.edu/resources/static-assets/exec-office-other/climate-change-full.pdf

[8] S. Rao, K. Riahi "The role of non-CO2 greenhouse gases in climate change mitigation: Longterm scenarios for the 21st century", The Energy Journal, c. 27, ss. 177-200, 2006.

[9] Manaki Whenua Landcare Research. (2019, 22 Şubat). Nitrous oxide inventory. [Çevrimiçi]. Erişim:https://www.landcareresearch.co.nz/science/greenhousegases/agriculturalgreenhousegases/nitru s-oxideinventory

[10] Phys.org. (2019, 28 Ocak). How the N2O greenhouse gas is decomposed. [Çevrimiçi]. Erişim: https://phys.org/news/2011-08-n2o-greenhouse-gas-decomposed.html

[11] The Conversation. (2019, 30 Ocak). Meet N2O, the greenhouse gas 300 times worse than CO2. [Çevrimiçi]. Erişim: http://theconversation.com/meet-n2o-the-greenhouse-gas-300-times-worse-thanco2-35204

[12] Science Daily. (2019, 30 Ocak). Emissions of greenhouse gases methane and nitrous oxide underestimated, research [Çevrimiçi]. Erişim: https://www.sciencedaily.com/releases/2010/07/ 100701090330.htm

[13] L. He, GH. Huang, H. Lu, "Greenhouse gas emissions control in integrated municipal solid waste management through mixed integer bilevel decision-making", Journal of Hazardous Materials, c. 193, ss. 112-119, 2011. 
[14] M. Brander, "Greenhouse Gases, $\mathrm{CO} 2, \mathrm{CO} 2 \mathrm{e}$, and Carbon: What Do All These Terms Mean?" Ecometria, ss.1-3, 2012. [Çevrimiçi]. Erişim: https://ecometrica.com/assets/GHGs-CO2-CO2e-andCarbon-What-Do-These-Mean-v2.1.pdf

[15] Danish Centre for Environment and Energy. (2019, 30 Ocak). Projection of greenhouse gases 2014-2025. [Çevrimiçi]. Erişim: https://dce2.au.dk/pub/SR194.pdf

[16] S. Solak, S. Pekküçükşen, "Türkiye'de Kentsel Katı Atık Yönetimi: Karşılaştırmalı Bir Analiz,” MANAS Sosyal Araştırmalar Dergisi, c. 7, s. 3, ss. 653-683, 2018.

[17] H. Palabıyı, A. Derya, Kentsel Katı Atıklar ve Yönetimi, Çevre Sorunlarına Çağdaş Yaklaşımlar, İstanbul, Türkiye: Beta, 2004.

[18] A. Yavaşcaoğlu, "Tekstil katı atıkları, katı atık oluşumunun azaltılması ve geri kazanımı". Mesleki Bilimler Dergisi (MBD), c. 1, s. 2, ss. 137-148, 2012.

[19] United Nations Environment Programme. (2019, 30 Ocak). Solid waste management (Volume I). [Çevrimiçi]. Erişim: https://www.eawag.ch /fileadmin/Domain/Abteilungen/sandec/E-Learning/ Moocs/Solid_Waste/W2/Solid_waste_management_UNEP_2005.pdf

[20] GK. Singh, K. Gupta, S. Chaudhary, "Solid Waste Management: Its Sources, Collection, Transportation and Recycling", International Journal of Environmental Science and Development, c. 5, s. 4, ss. 347-351, 2014.

[21] KO. Demirarslan, BY. Çelik, "Urban solid waste characterization in the east part of Black Sea region”, Global J. Environ. Sci. Manage, c. 4, s. 2, ss. 167-182, 2018.

[22] International Solid Waste Association (ISWA). (2019, 10 Şubat). Waste Management. [Çevrimiçi]. Erişim: http://www.sustentabilidad.uai.edu.ar / pdf / ing/waste_management.pdf

[23] Solid Waste Management. (2019, 15 Şubat). [Çevrimiçi]. Erişim: http://ec.europa.eu/echo/files/evaluation /watsan2005/annex_files/WEDC/es/ES07CD.pdf

[24] P. Alam, K. Ahmade, "Impact of Solid Waste on Health and The Environment". International Journal of Sustainable Development and Green Economics (IJSDGE), c. 2, ss. 165-168, 2013.

[25] C. Visvanathan, "Solid Waste and Climate Change: Perceptions and Possibilities". Proceeding of the International Conference on Solid Waste Management (Technical, Environmental and Socioeconomical Contexts), Khulna, Bangladesh, 2009.

[26] United Nations Environment Programme. (2019, 15 Şubat). Waste and Climate Change. [Online]. Erişim: http://www.unep.or.jp /ietc /Publications /spc / Waste \& Climate Change / Waste \& Climate Change.pdf

[27] E. Chalvatzaki, M. Lazaridis, "Estimation of greenhouse gas emissions from landfills: application to the Akrotiri landfill site (Chania, Greece)", Global NEST Journal, c. 12, s. 1, ss. 108-116, 2010.

[28] S. Manfredi, D. Tonini, TH. Chistensen, H. Scharff. "Landfilling of waste: accounting of greenhouse gases and global warming contributions", Waste Management \& Research, c. 27, s.8, ss. 825-836, 2009. 
[29] Final report to the European Commission, DG Environment. (2019, 15 Şubat). Waste management options and climate change. [Çevrimiçi]. Erişim: http://ec.europa.eu/environment /waste/ studies/pdf /climate_change.pdf

[30] Department of Energy \& Climate Change. (2019, 15 Şubat). 2014 UK Greenhouse Gas Emissions, Final [Çevrimiçi]. Erişim:https://assets.publishing.service.gov.uk/government/uploads/system/uploads/attachment_data/fi le/496942/2014_Final_Emissions_Statistics_Release.pdf

[31] Ontario Waste Management Association. (2019, 10 Ocak). Greenhouse Gas Emissions and the Ontario Waste Management Industry. [Çevrimiçi]. Erişim: http://www.cesarnet.ca / sites / default / files / pdf / publications / other /2015-GHGs-Waste-Mgmnt.pdf

[32] C. Larney, M. Heil, GA. Ha. (Erişim tarihi). "Case Studies from the Climate Technology Partnership: Landfill Gas Projects in South Korea and Lessons Learned", Technical Report, National Renewable Energy Laboratory, 2006. [Çevrimiçi]. Erişim: https://www.nrel.gov/docs /fy07osti / 40428.pdf

[33] JE. Bogner, KA. Spokas, JP. Chanton, "Seasonal Greenhouse Gas Emissions (Methane, Carbon Dioxide, Nitrous Oxide) from Engineered Landfills: Daily, Intermediate, and Final California Cover Soils", Journal of Environmental Quality, c. 40, ss. 1010-1020, 2011.

[34] Carbon Neutral Global Standard. (2019, 10 Ocak). [Çevrimiçi]. Erişim: https://www.carbonneutral.com / images / uploads / projects / Bantargebang_Landfill_Gas_Jan15.pdf

[35] International Institute for Sustainable Development. (2019, 10 Ocak). Greenhouse Gas Mitigation Options for Pakistan:Waste Sector. [Çevrimiçi]. Erişim: https://cdkn.org/wp-content / uploads / 2016 / 10 / fact-sheet-Pakistan-Waste-sector.pdf

[36] EEA greenhouse gas-data viewer. (2019, 01 Mart). [Online]. Erişim: https://www.eea.europa.eu/data-and-maps/data/data-viewers/greenhouse-gases-viewer

[37] R. Sanci, HO. Panarello, CO2 and CH4 Flux Measurements from Landfills-A Case Study: Gualeguaychú Municipal Landfill, Entre Ríos Province, Argentina, Greenhouse Gases-Emission, Measurement and Management. 2012. [Çevrimiçi]. Erişim: http://www.intechopen.com / boks / greenhouse-gases-emission-measurement-and-management/co2-and-ch4-flux-measurements-fromlandfill-a-case-study-gualeguaych-municipal-landfill-entre-r-os-p

[38] M. Pazoki, RM. Delarestaghi, MR. Rezvanian, R. Ghasemzade, P. Dalaei, "Gas Production Potential in the Landfill of Tehran by Landfill Methane Outreach Program", Jundishapur J Health Sci. c. 7, s. 4, ss. 20-25, 2015.

[39] NJ. Themelis, (2019, 10 Ocak). Waste-to-Energy: Renewable Energy Instead of Greenhouse Gas Emissions. [Çevrimiçi]. Erişim: http://citeseerx.ist.psu.edu/viewdoc/download_doi= 10.1.1.465.6158\&rep=rep1\&type=pdf

[40] SA. Pozza, CSG. Penteado, VG. Criscuolo, "A Greenhouse Gas Inventory in the Municipal Landfill of the City of Limeira, Brazil", Chemical Engineering Transactions, c. 43, ss. 2083-2088, 2015.

[41] A. Bouzonville, S. Atkins, S. Peng, "Review of long term landfill gas monitoring data and potential for use to predict emissions influenced by climate change", 21th Clean Air Society of Australia and New Zealand Conference, Sydney, Australia, September 2013.

[42] K. Wang-Yao, S. Towprayoon, C. Chiemchaisri, SH. Gheewala, A. Nopharatana, "Seasonal Variation of Landfill Methane Emissions from Seven Solid Waste Disposal Sites in Central Thailand", 
The 2nd Joint International Conference on Sustainable Energy and Environment (SEE 2006), Bangkok, Thailand, 2006.

[43] B. Hutton, "Waste management options to control greenhouse gas emissions - Landfill, compost or incineration?" Paper for the ISWA Conference, Portugal, 2009.

[44] EO. Işın, Determination of landfill gas by using methematical models, Yüksek lisans tezi, Dokuz Eylül Üniversitesi, Fen Bilimleri Enstitüsü, Çevre Mühendisliği Anabilim Dalı, İzmir, 2012.

[45] U.S. Environmental Protection Agency. (2019, 10 Ocak). [Çevrimiçi]. Erişim: https://www.epa.gov/sites/production/files/2016-09 / documents / pdh chapter2.pdf

[46] H. Sarptaş "Assessment of landfill gas (LFG) energy potential based on estimates of LFG models", Dokuz Eylül Üniversitesi Mühendislik Fakültesi, Fen ve Mühendislik Dergisi, c.18, s. 3-54, ss. 491-501, 2016.

[47] S. Thompson, S. Tanapat, "Modeling Waste Management Options for Greenhouse Gas Reduction", Journal of Environmental Informatics, c. 6, s. 1, ss.16-24, 2005.

[48] S. Kumar, Municipal Solid Waste Management in Developing Countries, Boca Raton, ABD: CRC Press Published, 2016.

[49] S. Karayılan, "Modelling and assessment of landfill gas generation at Afyonkarahisar landfill site" Master Thesis, The Graduate School of Natural and Applied Sciences of Middle East Technical University Ankara, Turkey, 2018.

[50] J. Jacobs, H. Scharff, (2019, 10 Ocak). Comparison of methane emission models and methane emission measurements [Çevrimiçi]. Erişim: https:// www.afvalzorg.nl / content / uploads / 2018 / 03 / Comparison-of-Methane-emission-models-to-Methane-emission-measurements.pdf.

[51] H. Scharff, J. Jacobs, "Applying guidance for methane emission estimation for landfills", Waste Management, c. 26, ss. 417-429, 2006.

[52] A. Sánchez, A. Artola, X. Font, T. Gea, R. Barrena, D. Gabriel, MÁ. Sánchez-Monedero, A. Roig, ML. Cayuela, C. Mondini, "Greenhouse gas emissions from organic waste composting", Environmental Chemistry Letters, c. 13, s. 3, ss. 223-238, 2015.

[53] Y. Yu, W. Zhang, "Greenhouse gas emissions from solid waste in Beijing: The rising trend and the mitigation effects by management improvements", Waste Management \& Research, DOI: 10.1177/0734242X16628982, 2016.

[54] Method for estimating greenhouse gas emission reductions from diversion of organic waste from landfills to compost facilities, (2019, 15 Ocak). Industrial Strategies Division Transportation and Toxics Division, [Çevrimiçi]. Erişim: https://www.arb.ca.gov/cc/waste/cerffinal.pdf

[55] U.S. Environmental Protection Agency Office of Resource Conservation and Recovery. (2019, 15 Ocak). Documentation for Greenhouse Gas Emission and Energy Factors Used in the Waste Reduction Model (WARM). [Çevrimiçi]. Erişim: https://www.epa.gov /sites /production /files/2016-03 /documents / warm _ v14_management practices.pdf

[56] E. Friedrich, C. Trois, "Quantification of greenhouse gas emissions from waste management processes for municipalities - A comparative review focusing on Africa" Waste Management, c. 31, ss. 1585-1596, 2011. 
[57] J. Oonk, A. Boom "Landfill gas formation, recovery and emissions, Dutch National Research Programme on Global Air "Pollution and Climate Change". 1995. [Çevrimiçi]. Erişim: https://publications.tno.nl / publication /.../MEP-1995-203.pdf

[59] EO. Taşkan, "Depolama sahası gazlarının yönetimi ve modellemesi”, Yüksek lisans tezi, İstanbul Teknik Üniversitesi, Fen Bilimleri Enstitüsü, Çevre Mühendisliği Bölümü, İstanbul, Türkiye, 2001.

[60] European Commission. (2019, 15 Ocak). Reference Document on the Best Available Techniques for Waste Incineration. [Çevrimiçi]. Erişim: http://eippcb.jrc.ec.europa eu / reference / BREF / wi _bref_0806.pdf

[61] M. Çelebi, B. Dökmetaş, B. Sönmez, N. Akçam, "Belediye Atıklarından Çöp Gazı (LandFill Gas-LFG) Elde Edilerek Elektrik Enerjisi Üretilmesi ve Ülkemizdeki Örneklerinin İncelenmesi" 5th International Symposium on Innovative Technologies in Engineering and Science, Baku-Azerbaijan, 2017. 